\title{
RHEUMATIC COMPLAINTS IN URBAN AND RURAL POPULATIONS IN OSAKA
}

\author{
BY \\ KANJI SHICHIKAWA, AKIRA MAYEDA, YOSHIO KOMATSUBARA, \\ TADASHI YAMAMOTO, OSAMU AKABORI, ICHIRO HONGO, TOYOJI \\ KOSUGI, AND TOSHIHIKO MIYAUCHI \\ Department of Orthopaedic Surgery, Osaka University Medical School, Osaka \\ AND \\ MASAMI ORIHARA AND AKIRA TANIGUCHI \\ Orthopaedic Unit, Kansai-Rosai Hospital, Amagasaki, Japan
}

This survey was made to obtain reliable data for the prevalence of rheumatic complaints in Toyonaka and in Tojo, Tondabayashi. The population sample was examined at home by physicians experienced in the diagnosis of rheumatic diseases. Inquiry was made into all rheumatic complaints especially rheumatoid arthritis in both urban and rural areas.

\section{The Method of Survey}

Toyonaka and the Tojo district in Tondabayashi in the suburbs of Osaka were selected as representative urban and rural areas. Toyonaka lies north-west of Osaka, and is a residential area with a population of about 215,000 . Tondabayashi lies at the foot of the Kongo mountains which bound the south-eastern part of the Osaka plain, and has a population of about 38,000 . The rural locality is the Tojo district, an area surrounded by tangerine-growing mountains and recently incorporated into Tondabayashi.

At the time of the survey the population of Toyonaka showed a monthly increase of 0.5 per cent., the increase from immigration being four times higher than the natural increase. Tojo, Tondabayashi, showed a very low monthly increase $(0.09$ per cent.), the natural increase being slightly in excess of the decrease by emigration.

Regarding the occupations of families, office jobs and labouring account for 67 per cent. in Toyonaka, and farming for $\mathbf{7 2}$ per cent. in Tojo (Table I).

TABLE I

ROUGH CLASSIFICATION OF OCCUPATIONS OF HOUSEHOLDS SURVEYED (PERCENTAGE)

\begin{tabular}{|c|c|c|c|c|c|c|}
\hline Area & & $\underset{\text { ing }}{\text { Farm- }}$ & $\begin{array}{l}\text { Office } \\
\text { Work }\end{array}$ & $\begin{array}{c}\text { Labour- } \\
\text { ing }\end{array}$ & $\begin{array}{l}\text { Com- } \\
\text { merce }\end{array}$ & Others \\
\hline $\begin{array}{l}\text { Toyonaka . } \\
\text { Tojo, } \\
\text { Tondabayashi }\end{array}$ & $\cdots$ & $\begin{array}{r}3 \\
72\end{array}$ & $\begin{array}{l}50 \\
17\end{array}$ & $\begin{array}{r}17 \\
1\end{array}$ & $\begin{array}{r}11 \\
2\end{array}$ & $\begin{array}{r}19 \\
8\end{array}$ \\
\hline Total &. & 27 & 38 & 11 & 8 & 16 \\
\hline
\end{tabular}

The survey was made during June and July 1961 in Toyonaka, and during January and February 1962 in Tondabayashi.

In Toyonaka, subjects were selected at random from a schedule made by the Welfare Minister in connexion with a population survey of pulmonary tuberculosis a few months previously. This provided information about household composition, economic status, and health conditions. For this schedule, the whole population of the ten districts selected was surveyed. In the Tojo district all the families were interviewed beforehand by medico-social case workers at a health-centre in the area and information was collected about health and economic status.

Doctors in charge of the Rheumatic Clinic at the Department of Orthopaedic Surgery, Osaka University Medical School, interviewed the families at home, and asked whether they had suffered or were suffering from rheumatism, lumbago, sciatica, shoulder pain, arthralgia, arthritis, or any other aches or pains. Positive answers were followed by a check of the medical history; the rheumatic complaints were investigated by simple clinical examinations and were classified, if possible, into the pre-determined diagnostic categories.

However, a single clinical examination is not always sufficient to diagnose cases of rheumatic diseases, particularly transient painful episodes of fibrositis, neuritis, myalgia and lumbago. A diagnosis of osteo-arthrosis or intervertebral disk degeneration was established only in those with marked clinical and $x$-ray findings, although a more detailed examination would have identified more such cases. Patients whose diagnoses were equivocal, or who required further examination were referred to their respective health centres or asked to visit the Rheumatic Clinic, Osaka University; 43 patients in Toyonaka and 49 in Tojo responded, giving completion rates of 35 and 100 per cent. respectively. Patients with limited mobility were $x$ rayed at home and had specimens of blood taken. The diagnosis of rheumatoid arthritis was based upon clinical signs, radiological findings, and serological tests. A diagnosis of definite or probable 
rheumatoid arthritis was established according to the criteria of the American Rheumatism Association (Ropes, Bennett, Cobb, Jacox, and Jessar, 1957).

The survey covered 779 families and 2,996 persons (1,465 males and 1,531 females) in Toyonaka, and 396 families and 2,023 people (1,035 males and 988 females) in Tojo (completion rates of 90.3 and 97 per cent. respectively). Those older than 65 years were predominant in Tojo $(P<0.01)$, and those of 25 to 34 years in Toyonaka $(\mathbf{P}<\mathbf{0} \cdot 01)$.

\section{Results}

Painful complaints of all kinds were found in 595 (12 per cent.); 295 (10 per cent.) in Toyonaka and 300 (15 per cent.) in Tojo.

The slightly higher figure for the rural area is statistically significant $(P<0 \cdot 01)$. The difference might be partly due to the fact that the survey in Tojo was made during the winter, though the year happened to be unseasonably warm. It must also be taken into consideration that the people of Toyonaka have easy access to physicians, while in Tojo there is only one doctor's consultıng room so that mild cases are likely to be left untreated. Those with a past history of rheumatic diseases numbered 185 in Toyonaka and 81 in Tojo.

\section{Prevalence of Rheumatic Complaints}

Rheumatic complaints were found in 334 cases ( 7 per cent.); 161 (5 per cent.) in Toyonaka and 173 ( 9 per cent.) in Tojo, with a dominance in the latter $(P<0.01)$. If those with past history are added, there are 271 cases ( 9 per cent.) in the former and 206 cases (10 per cent.), in the latter, showing little difference (Table II).
The prevalence of rheumatic diseases was classi- 궁 fied as follows:

\section{A. Inflammatory Rheumatic Arthritis}

(a) Rheumatoid Arthritis.-There were ten $\vec{\Rightarrow}$ female cases of definite rheumatoid arthritis and five? (one male, four females) of probable rheumatoide arthritis, totalling fifteen cases $(0 \cdot 3$ per cent.) for the two areas (Table II). No difference was observec between the two areas. The prevalence among adults of over 20 years of age was 0.5 per centis Functional disturbances of Class 3 were found in $\vec{b}$ three cases $(0.06$ per cent. of the whole populationand 0.09 per cent. of those above 20 years of age). $\vec{\omega}$ These rheumatoid arthritis cases are listed in Table III (opposite).

No family had more than one case of rheumatoidi arthritis, but there were two instances of familialaggregation of subacute rheumatic arthritis.

The sensitized sheep-cell agglutination test (S.C.A.T.: Heller-Svartz's method) and slide latexfixation test were performed in eleven cases, six (55 per cent.) of which were positive in both tests.

Regarding living conditions, most of the cases occurred in families with four to six members, occasionally as many as eight. Economically, threeo belonged to an upper class, eight were middle class, and four were a lower class. Ten lived in a farming or low marsh area, and five in a residential area.

\section{(b) Other Arthritis (Table IV, opposite)}

(i) Rheumatic Fever.-One man was found to have rheumatic fever and two cases (one male. one female $\vec{S}$ had a past history. It must be conceded that this disease

TABLE II

TOTAL RHEUMATIC COMPLAINTS AND CASES OF RHEUMATOID ARTHRITIS, BY AGE AND SEX, IN TOYONAKA AND TOJO. TONDABAYASHI

\begin{tabular}{|c|c|c|c|c|c|c|c|c|c|c|c|c|c|c|c|}
\hline \multirow{3}{*}{ Area } & \multirow{3}{*}{$\begin{array}{c}\text { Age } \\
\text { (years) }\end{array}$} & & & \multicolumn{6}{|c|}{ Total Rheumatic Complaints } & \multicolumn{6}{|c|}{ Rheumatoid Arthritis } \\
\hline & & \multicolumn{2}{|c|}{ Sex } & \multicolumn{2}{|c|}{ Male } & \multicolumn{2}{|c|}{ Female } & \multicolumn{2}{|c|}{ Total } & \multicolumn{2}{|c|}{ Male } & \multicolumn{2}{|c|}{ Female } & \multicolumn{2}{|c|}{ Total } \\
\hline & & Male & Female & No. & $\begin{array}{c}\text { Per } \\
\text { cent. }\end{array}$ & No. & $\begin{array}{c}\text { Per } \\
\text { cent. }\end{array}$ & No. & $\begin{array}{c}\text { Per } \\
\text { cent. }\end{array}$ & No. & $\begin{array}{l}\text { Per } \\
\text { cent. }\end{array}$ & No. & $\begin{array}{c}\text { Per } \\
\text { cent. }\end{array}$ & No. & $\begin{array}{r}\text { Per } \\
\text { cent }\end{array}$ \\
\hline \multirow[t]{2}{*}{ Toyonaka } & $\begin{array}{l}-14 \\
15-24 \\
25-34 \\
35-44 \\
45+\end{array}$ & $\begin{array}{l}405 \\
272 \\
238 \\
185 \\
365\end{array}$ & $\begin{array}{l}361 \\
293 \\
278 \\
207 \\
392\end{array}$ & $\begin{array}{r}1 \\
1 \\
2 \\
5 \\
40\end{array}$ & $\begin{array}{r}0 \cdot 2 \\
0 \cdot 4 \\
1 \\
3 \\
11\end{array}$ & $\begin{array}{r}1 \\
4 \\
15 \\
26 \\
66\end{array}$ & $\begin{array}{r}0 \cdot 3 \\
1 \cdot 4 \\
5 \\
13 \\
17\end{array}$ & $\begin{array}{r}2 \\
5 \\
17 \\
31 \\
106\end{array}$ & $\begin{array}{r}0 \cdot 3 \\
0 \cdot 9 \\
3 \\
8 \\
14\end{array}$ & & & $\begin{array}{l}2 \\
6\end{array}$ & & $\begin{array}{l}2 \\
6\end{array}$ & \\
\hline & Total & 1,465 & 1,531 & 49 & 3 & 112 & 9 & 161 & 5 & & & 8 & $0 \cdot 5$ & 8 & $0 \cdot 3$ \\
\hline \multirow[t]{2}{*}{ Tojo, Tondabayashi . . } & $\begin{array}{l}-14 \\
15-24 \\
25-34 \\
35-44 \\
45+\end{array}$ & $\begin{array}{l}305 \\
199 \\
144 \\
121 \\
266\end{array}$ & $\begin{array}{l}247 \\
153 \\
127 \\
141 \\
320\end{array}$ & \begin{tabular}{l|l}
1 \\
1 \\
4 \\
8 \\
48
\end{tabular} & $\begin{array}{r}0.3 \\
0.5 \\
3 \\
7 \\
21\end{array}$ & $\begin{array}{r}0 \\
2 \\
11 \\
13 \\
85\end{array}$ & $\begin{array}{r}0 \\
1 \cdot 3 \\
9 \\
9 \\
27\end{array}$ & $\begin{array}{r}1 \\
3 \\
15 \\
21 \\
133\end{array}$ & $\begin{array}{r}0.2 \\
0.9 \\
6 \\
8 \\
23\end{array}$ & 1 & & $\begin{array}{l}2 \\
4\end{array}$ & & $\begin{array}{l}2 \\
5\end{array}$ & \\
\hline & Total & 1,035 & 988 & 62 & 6 & 111 & 11 & 173 & 9 & 1 & $0 \cdot 1$ & 6 & $0 \cdot 6$ & 7 & $0 \cdot 3$ \\
\hline
\end{tabular}


TABLE III

CLINICAL FEATURES OF RHEUMATOID ARTHRITIS PATIENTS

\begin{tabular}{|c|c|c|c|c|c|c|c|c|c|}
\hline Area & $\begin{array}{c}\text { No. } \\
\text { of Cases }\end{array}$ & $\begin{array}{c}\text { Age } \\
\text { (years) }\end{array}$ & Sex & Diagnosis & $\begin{array}{c}\text { Known } \\
\text { Duration } \\
\text { (years) }\end{array}$ & Stage & Class & $\begin{array}{c}\text { RA Test } \\
\text { (Slide Latex- } \\
\text { Fixation) }\end{array}$ & $\underset{\text { Titre }}{\text { \#.C.A.T. }}$ \\
\hline Toyonaka & $\begin{array}{l}1 \\
2 \\
3 \\
4 \\
5 \\
6 \\
7 \\
8\end{array}$ & $\begin{array}{l}50 \\
74 \\
36 \\
25 \\
51 \\
51 \\
62 \\
27\end{array}$ & $\begin{array}{l}\text { Female } \\
\text { Female } \\
\text { Female } \\
\text { Female } \\
\text { Female } \\
\text { Female } \\
\text { Female } \\
\text { Female }\end{array}$ & $\begin{array}{l}\text { Definite } \\
\text { Definite } \\
\text { Definite } \\
\text { Definite } \\
\text { Definite } \\
\text { Probable } \\
\text { Probable } \\
\text { Probable }\end{array}$ & $\begin{array}{l}10 \\
20 \\
7 \\
5 \\
5 \\
1 \\
3 \\
0 \cdot 17\end{array}$ & $\begin{array}{l}4 \\
4 \\
4 \\
3 \\
2\end{array}$ & $\begin{array}{l}2 \\
2 \\
3 \\
1 \\
2\end{array}$ & $\begin{array}{l}? \\
? \\
+ \\
+ \\
? \\
\pm \\
=\end{array}$ & $\begin{array}{r}? \\
? \\
56 \\
112 \\
? \\
? \\
28 \\
28\end{array}$ \\
\hline Tojo & $\begin{array}{r}9 \\
10 \\
11 \\
12 \\
13 \\
14 \\
15\end{array}$ & $\begin{array}{l}77 \\
74 \\
70 \\
78 \\
52 \\
61 \\
39\end{array}$ & $\begin{array}{l}\text { Female } \\
\text { Female } \\
\text { Female } \\
\text { Female } \\
\text { Female } \\
\text { Male } \\
\text { Female }\end{array}$ & $\begin{array}{l}\text { Definite } \\
\text { Definite } \\
\text { Definite } \\
\text { Definite } \\
\text { Definite } \\
\text { Probable } \\
\text { Probable }\end{array}$ & $\begin{array}{r}20 \\
10 \\
4 \\
30 \\
30 \\
1 \\
3\end{array}$ & $\begin{array}{l}4 \\
4 \\
3 \\
4 \\
4\end{array}$ & $\begin{array}{l}3 \\
3 \\
2 \\
2 \\
2\end{array}$ & $\begin{array}{c}- \\
++ \\
+ \\
+ \\
+ \\
?\end{array}$ & $\begin{array}{r}14 \\
112 \\
28 \\
56 \\
28 \\
56 \\
56\end{array}$ \\
\hline
\end{tabular}

$* \geq 56$ defined positive.

TABLE IV

RHEUMATIC COMPLAINTS, BY DIAGNOSTIC CLASSIFICATION AND SEX, IN TOYONAKA AND TOJO, TONDABAYASHI

\begin{tabular}{|c|c|c|c|c|c|c|c|c|c|c|c|c|c|c|c|c|}
\hline \multirow{3}{*}{\multicolumn{3}{|c|}{ Diagnosis }} & \multicolumn{7}{|c|}{ Toyonaka } & \multicolumn{7}{|c|}{ Tojo, Tondabayashi } \\
\hline & & & \multicolumn{3}{|c|}{$\begin{array}{c}\text { Complaints at Time } \\
\text { of Survey }\end{array}$} & \multicolumn{3}{|c|}{$\begin{array}{l}\text { Complaints in Past } \\
\text { History }\end{array}$} & \multirow{2}{*}{ Total } & \multicolumn{3}{|c|}{$\begin{array}{l}\text { Complaints at Time } \\
\text { of Survey }\end{array}$} & \multicolumn{3}{|c|}{$\begin{array}{l}\text { Complaints in Past } \\
\text { History }\end{array}$} & \multirow{2}{*}{ Total } \\
\hline & & & Male & Female & Total & Male & Female & Total & & Male & Female & Total & Male & Female & Total & \\
\hline Total Surveyed & . & $\cdots$ & 1,465 & 1,531 & 2,996 & 1,465 & 1,531 & 2,996 & 2,996 & 1,035 & 988 & 2,023 & 1,035 & 988 & 2,023 & 2,023 \\
\hline \multicolumn{3}{|c|}{$\begin{array}{c}\text { Inflammatory Rheumatic } \\
\text { Arthritis } \quad \ldots\end{array}$} & 2 & 24 & $\begin{array}{r}26 \\
(0.9)\end{array}$ & 7 & 10 & 17 & $\begin{array}{r}43 \\
(1 \cdot 4)\end{array}$ & 2 & 8 & $\begin{array}{r}10 \\
(0 \cdot 5)\end{array}$ & 5 & 4 & 9 & $\begin{array}{r}19 \\
(0 \cdot 8)\end{array}$ \\
\hline \multicolumn{3}{|c|}{$\begin{array}{l}\text { Rheumatoid Arthritis } \\
\text { Rheumatic Fever .. } \\
\text { Subacute Rheumatic } \\
\text { Arthritis } \\
\text { Palindromic Rheumatism } \\
\text { Monarthritis .. }\end{array}$} & 1 & $\begin{array}{l}5 \\
2 \\
9\end{array}$ & $\begin{array}{r}8 \\
(0 \cdot 3) \\
1 \\
5 \\
2 \\
10\end{array}$ & 2 & $\begin{array}{l}1 \\
6\end{array}$ & $\begin{array}{l}1 \\
8\end{array}$ & $\begin{array}{r}8 \\
(0 \cdot 3) \\
2 \\
13 \\
(0 \cdot 4) \\
2 \\
18 \\
(4 \cdot 6)\end{array}$ & 1 & 6 & $\begin{array}{r}7 \\
(0 \cdot 3)\end{array}$ & $\begin{array}{l}1 \\
2\end{array}$ & 4 & $\begin{array}{l}1 \\
6\end{array}$ & $\begin{array}{r}7 \\
(0 \cdot 3) \\
1 \\
6 \\
(0 \cdot 3) \\
1 \\
4 \\
(0 \cdot 2)\end{array}$ \\
\hline \multicolumn{3}{|c|}{ Nonarticular Rheumatism } & 21 & 51 & $\begin{array}{r}72 \\
(2 \cdot 4)\end{array}$ & 21 & 29 & $\begin{array}{r}50 \\
(1 \cdot 7)\end{array}$ & $\begin{array}{r}122 \\
(4 \cdot 1)\end{array}$ & 23 & 41 & $\begin{array}{r}64 \\
(3 \cdot 1)\end{array}$ & 3 & 11 & $\begin{array}{r}14 \\
(0 \cdot 7)\end{array}$ & $\begin{array}{r}78 \\
(3 \cdot 8)\end{array}$ \\
\hline \multicolumn{2}{|c|}{ Degenerative Rheumatism } & . & 22 & 34 & $\begin{array}{r}56 \\
(1 \cdot 9)\end{array}$ & 24 & 19 & $\begin{array}{r}43 \\
(1 \cdot 4)\end{array}$ & $\begin{array}{c}99 \\
(2 \cdot 6)\end{array}$ & 35 & 60 & $\begin{array}{r}95 \\
(4 \cdot 7)\end{array}$ & 4 & 6 & $\begin{array}{r}10 \\
(0 \cdot 5)\end{array}$ & $\begin{array}{r}105 \\
(5 \cdot 2)\end{array}$ \\
\hline \multicolumn{2}{|c|}{$\begin{array}{l}\text { Osteo-arthrosis } \\
\text { Disk Degeneration } \\
\text { with Root Symptoms }\end{array}$} & $\cdots$ & $\begin{array}{r}5 \\
4 \\
13\end{array}$ & $\begin{array}{r}18 \\
3 \\
13\end{array}$ & $\begin{array}{r}23 \\
(0 \cdot 8) \\
7 \\
(0 \cdot 2) \\
26 \\
(0 \cdot 9)\end{array}$ & $\begin{array}{r}9 \\
15\end{array}$ & $\begin{array}{r}9 \\
10\end{array}$ & $\begin{array}{r}18 \\
(0 \cdot 6) \\
25 \\
(0 \cdot 8)\end{array}$ & $\begin{array}{r}23 \\
(0.8) \\
25 \\
(0.8) \\
51 \\
(1 \cdot 7)\end{array}$ & $\begin{array}{r}17 \\
3 \\
15\end{array}$ & $\begin{array}{r}40 \\
5 \\
15\end{array}$ & $\begin{array}{c}57 \\
(2 \cdot 8) \\
8 \\
(0 \cdot 4) \\
30 \\
(1 \cdot 5)\end{array}$ & $\begin{array}{l}1 \\
3\end{array}$ & $\begin{array}{l}2 \\
4\end{array}$ & $\begin{array}{r}3 \\
7 \\
(0 \cdot 3)\end{array}$ & $\begin{array}{r}57 \\
(2 \cdot 8) \\
11 \\
(0 \cdot 5 \\
37 \\
(1 \cdot 8)\end{array}$ \\
\hline Total Complaints & $\cdots$ & $\cdots$ & 45 & 109 & 154 & 52 & 58 & 110 & 264 & 60 & 109 & 169 & 12 & 21 & 33 & 202 \\
\hline
\end{tabular}

Numbers in brackets are percentages.

is occasionally overlooked and cases with a past history may have been more numerous than those actually detected.

(ii) Subacute Rheumatic Arthritis.-The diagnosis of subacute rheumatic arthritis was based upon the reports of Ravault, Vignon, and Robert (1958). Five women were suffering from the disease; four men and ten women seemed to have had it in the past. (iii) Palindromic Rheumatism.-This disease requires careful observation and examination. One man and two women had features suggestive of the disease.

(iv) Monarthritis.-One man and eleven women were found to have this disease, and seven men and three women had a past history of it.

Some of those with inflammatory rheumatic arthritis other than rheumatoid arthritis had been 
previously diagnosed as cases of rheumatoid arthritis. Some of those with a past history had had a clinical course suggestive of rheumatoid arthritis, but since they were free from residual changes in the joints, a diagnosis of rheumatoid arthritis was not definitely established.

Inflammatory rheumatic arthritis was found in 26 cases $(0.9$ per cent.) in Toyonaka and ten $(0.5$ per cent.) in Tojo; if those with a past history are added, there would be $43(1.4$ per cent.) in the former and nineteen $(0.8$ per cent.) in the latter, the incidence in the former being apparently higher $(0.1>P$ $>0.05$ ).

\section{B. Nonarticular Rheumatism}

This heading includes various complaints, such as poly- or monoarthralgia, fibrositis, bursitis, myositis, myalgia, tendinitis, tendovaginitis, peritendinitis, neuritis, neuralgia, neuropathy, frozen shoulder, and benign dorsalgia. There were 72 cases $(2 \cdot 4$ per cent) of nonarticular rheumatism in Toyonaka and 64 (3.1 per cent.) in Tojo; if a past history is included, there are $122(4 \cdot 1$ per cent.) in the former and $78(3.8$ per cent.) in the latter.

\section{Degenerative Rheumatism}

(a) Osteo-arthrosis.-The prevalence of this condition varies according to whether the diagnosis rests on $x$-ray findings or on clinical signs only. The present survey was based on clinical findings. Persons who reported difficulty in performing their daily activities were examined, revealing 23 cases $(0.8$ per cent.) in Toyonaka, and 57 ( 2.8 per cent.) in Tojo, the prevalence in the latter being significantly greater $(\mathrm{P}<0.01)$. Since Tojo is inhabited by many elderly people, these figures do not necessarily indicate a true difference, but, when matched age groups are compared, Tojo still shows a higher incidence.

Most cases showed involvement of the knees. Eight cases of polyarthrosis (two men, six women) were found to have Heberden's nodes: three women in Toyonaka, and two men and three women Tojo. One man in Tojo had Bouchard's nodes.

(b) Intervertebral Disk Degeneration.-Those who complained of lumbago at the time of question:ing numbered $26(0.9$ per cent.) in Toyonaka an $\overline{\bar{\omega}}$ thirty ( 1.5 per cent.) in Tojo. Root symptoms were found in four men and three women $(0 \cdot 2$ per cent in Toyonaka, and three men and five women $(0 \cdot \overline{\bar{\alpha}}$ per cent.) in Tojo.

\section{Other Rheumatic Complaints}

The following diagnoses were established:

\section{Traumatic arthritis}

Scleroderma

Erythema nodosum Gout

Psychogenic Rheumatism
Two men and one woman.

One man.

Two women.

Three men (including suspect) and orie woman suspect.

One woman.
In all complaints in this miscellaneous group were found in four men and three women, in Toyonak and two men and two women in Tojo.

Of cases of gout, two men had attacks of pain hyperuricaemia, and $x$-ray changes, leaving the diagnosis in no doubt; but one male case was conn sidered equivocal despite hyperuricaemia ind attacks of pain. The one woman had inflammato in the first metatarsophalangeal joint, but detailed examination was made.

\section{Comparison with Previous Surveys}

These results were compared with those Kellgren, Lawrence, and Aitken-Swan (1953) Leigh in Lancashire.

The surveys at Leigh and Toyonaka were con ducted in a comparable way in the two towns, buf the former is industrial while the latter is residentia $\mathrm{B}$. A direct comparison would be misleading, but soms outstanding differences between the two population emerge (Table V).

TABLE V

COMPARISON BETWEEN SURVEYS OF LEIGH AND TOYONAKA

\begin{tabular}{|c|c|c|c|c|c|c|c|c|c|c|c|c|}
\hline \multirow{2}{*}{ Area } & \multirow{2}{*}{ Date } & \multirow{2}{*}{$\begin{array}{c}\text { Total } \\
\text { Questioned }\end{array}$} & \multicolumn{2}{|c|}{$\begin{array}{l}\text { Total } \\
\text { Complaints }\end{array}$} & \multicolumn{2}{|c|}{$\begin{array}{r}\text { Osteo- } \\
\text { arthrosis }\end{array}$} & \multicolumn{2}{|c|}{$\begin{array}{l}\text { Rheumatoid } \\
\text { Arthritis }\end{array}$} & \multicolumn{2}{|c|}{$\begin{array}{c}\text { Disk } \\
\text { Disorders }\end{array}$} & \multicolumn{2}{|c|}{ Undetermined } \\
\hline & & & No. & $\begin{array}{c}\text { Per } \\
\text { cent. }\end{array}$ & No. & $\begin{array}{l}\text { Per } \\
\text { cent. }\end{array}$ & No. & $\begin{array}{c}\text { Per } \\
\text { cent. }\end{array}$ & No. & $\begin{array}{c}\text { Per } \\
\text { cent. }\end{array}$ & No. & 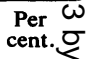 \\
\hline Leigh & $(1945-50)$ & $\begin{array}{c}2,898 \\
(15+)\end{array}$ & 541 & $18 \cdot 7$ & 185 & $6 \cdot 4$ & 70 & $2 \cdot 4$ & 79 & $2 \cdot 7$ & 155 & $5 \cdot 3 \frac{\varrho}{\frac{C}{\sigma}}$ \\
\hline Toyonaka & (1961) & $\begin{array}{c}2,230 \\
(15+)\end{array}$ & 161 & $7 \cdot 2$ & 23 & $1 \cdot 0$ & 8 & $\begin{array}{c}0.4 \\
(* 0.5)\end{array}$ & 33 & $1 \cdot 5$ & 72 & $3 \cdot 2=$ \\
\hline
\end{tabular}

* If subacute rheumatic arthritis cases are included. 
Total complaints are much lower in Toyonaka than in Leigh $(P<0.001)$. The most significant difference was observed in the prevalence of rheumatoid arthritis and osteo-arthrosis. The groups made up by disk disorders (including lumbago and sciatica) and "pains undetermined" by Kellgren and others (which seem to correspond to nonarticular rheumatism, except lumbago, following the present classification) show a smaller but still significant difference. The low prevalence of osteo-arthrosis in the Japanese might be due to a high complaint threshold, because, in another survey carried on later in another urban district, clinical examination disclosed a prevalence of 6 per cent. of osteo-arthrosis, while subjective complaints accounted for only about 1 per cent.; however, in all the cases of rheumatoid arthritis the complaints corresponded to the clinical findings. These apparent differences may, however, be largely due to the fact that there was a much greater proportion of people above the age of 45 years in Leigh than in Toyonaka.

\section{Discussion}

Osaka, where the present survey was conducted, belongs to a temperate zone which enjoys a mild climate. Since rheumatic diseases are considered to be aetiologically influenced by environmental factors, the present data based upon a mild climate do not always seem to represent the incidence throughout Japan, where there are local climatic variations.

The survey revealed that rheumatoid arthritis was present in 0.3 per cent. of the whole population studied, 0.06 per cent. having Class 3 functional impairment or more. One case had never been seen by a physician until detected in the survey.

The present result shows little difference from the prevalence of 0.028 per cent. obtained in a joint survey of the handicapped and disabled by the Japanese Orthopaedic Association and Welfare Ministry in 1952 or the figure of 0.07 per cent. (28 cases out of 41,945 subjects) from the National Health Survey 1959).

According to Oshima, Ishizaki, Sasaki, and Kojima (1960) the prevalence of rheumatoid arthritis in people over 21 years old is $2 \cdot 2$ per cent. at Tadao (Village), Tokyo, and 0.6 per cent. in Yoshihara City, Shizuoka, and for all age groups it is $0.81 \mathrm{per}$ cent. in Haibara, Shizuoka. These percentages are higher than those obtained in the present survey $(0.3$ per cent. for all age groups and 0.5 per cent. for those over 20 years of age). If a diagnosis is made on the basis of stricter criteria, the prevalence of 0.3 per cent. obtained in the Osaka area may be representative of the whole of Japan.

The prevalence in other countries seems higher than in Japan in the age groups covered. The prevalence among Eskimos in Greenland was 0.3 per cent. which is similar to that in Japan (Blumberg, Bloch, Black, and Dotter, 1961). Admittedly in such comparisons one must remember differences in survey methods, criteria of diagnosis, and subjects studied. Nevertheless, it seems that the incidence of rheumatoid arthritis may vary according to race.

In the Osaka area as a whole, no difference was observed in the prevalence of rheumatoid arthritis between Toyonaka and Tojo, despite different environmental conditions. No particular living conditions distinguished the families of patients from other families.

It will be important to decide whether differences in the prevalence of rheumatoid arthritis are dependent upon differences in race, geography, climate, or living conditions in terms of mental attitudes. It is interesting that rheumatoid arthritis was five times more common in Leigh than in Toyonaka, even if subacute cases are included in the latter.

The prevalence of rheumatic complaints was 7 per cent., or 10 per cent. if a past history is added. The incidence of tuberculosis (including a past history) was 1.4 per cent. and of hypertension and heart disease 1.8 per cent. In 1955-56 in England and Wales 67 per cent. of a population of 382,829 persons sought medical advice for some reason; of these $7 \cdot 1$ per cent. were cases of chronic rheumatic disease (Sze, 1963). Kellgren and others (1953) found 19 per cent. of rheumatic complaints at the time of questioning and 33 per cent. during a 5-year period.

It is predicted that the pattern of incidence of rheumatic diseases may change. At present, Tojo maintains a higher prevalence ( 9 per cent.) than Toyonaka ( 5 per cent.), but, if past history is included, little difference remains, the figures being 10 and 9 per cent. respectively. Differences in the living conditions in the two areas may play some part, but ease of access to medical advice seems to be more important, since the town dwellers can consult a doctor more easily.

The difference, though statistically insignificant, in the prevalence of inflammatory rheumatic arthritis between Toyonaka ( 26 cases) and Tojo (ten cases) may indicate a possible influence of mental attitudes in a busy city on the development of arthritis. The investigation by Miall, Ball, and Kellgren (1958) of urban and rural populations in South Wales suggested a higher prevalence of rheumatoid arthritis in the urban area. Their results cannot safely be compared with ours, because of different criteria of diagnosis, but there may be a general trend for rheumatic arthritis to be more 
frequent in town than country. Inflammatory rheumatic arthritis is much more frequent in women (32 females against four males), a sex difference that has been observed by several authors, including Bremner (1961) and Kellgren and Lawrence (1956).

There was a much greater prevalence of osteoarthrosis in Tojo ( 2.8 per cent.) than in Toyonaka $(0.8$ per cent.). The farmers of Tojo grow tangerines on mountain slopes where they work with heavy loads on their backs. Oshima (1961) reported a prevalence of arthrosis in the Haibara district, Shizuoka Prefecture, as $1 \cdot 3$ per cent., not dissimilar from the average of 1.6 per cent. for Toyonaka and Tojo. Oshima (1961) reported that lumbago and sciatica accounted for 0.8 per cent. and degenerative spondylosis for $1 \cdot 3$ per cent., again apparently showing little difference from the present results. The prevalence of osteo-arthrosis in Japan seems to be much lower than that in Leigh; this may be partly due to a high complaint threshold in the Japanese, and also to the larger proportion of older persons in Leigh. The age distribution reported by Kellgren and others (1953) does not alone seem sufficient to explain this wide difference, and another survey made by the present authors showed a higher prevalence of osteo-arthrosis with a lower rate of complaints.

Cases of disk degeneration with nerve root symptoms accounted for $\mathbf{0 . 3}$ per cent., which is the same as in Leigh; this gives further support to the suggestion made above.

\section{Summary}

(1) A survey was made of the prevalence of rheumatic complaints in the urban population of Toyonaka and the rural population of Tojo, Tondabayashi, in Osaka, a total of 5,019 persons belonging to 1,175 families.

(2) The overall prevalence of rheumatic complaints was 7 per cent., with a slightly higher prevalence in the rural area. When past history was included, there was little difference between the two areas.

(3) Rheumatoid arthritis was found in 0.3 per cent. in the whole population, with little difference between the two areas.

(4) Inflammatory rheumatic arthritis was found in 0.9 per cent. in Toyonaka and 0.5 per cent. in Tojo. When past history was included, there was 1.4 per cent. in the former and 0.8 per cent. in the latter.

(5) Nonarticular rheumatic disease was found in about 3 per cent. (about 4 per cent. if past history was included).
(6) Disk disorders (lumbago and nerve roळt symptoms) were seen in 2.3 per cent. in both aresss surveyed and osteo-arthrosis 1.6 per cent., with an excess for the rural area over the urban area.

(7) The results were compared with those Leigh, England. The prevalence of rheumatic complaints, especially of rheumatoid arthritis a probably of osteo-arthrosis, was much lower Japan.

The authors wish to express their thanks to Prof. J. $\tilde{\mathrm{H}}$ Kellgren for his kind suggestions.

\section{REFERENCES}

Blumberg, B. S., Bloch, K. J., Black, R. L., and Dotter, (1961). Arthr. and Rheum., 4, 325.

Bremner, J. M. (1961). Ann. rheum. Dis., 20, 149. Kellgren, J. H., and Lawrence, J. S. (1956). Ibid., 15,-1. $\longrightarrow,-$, and Aitken-Swan, J. (1953). Ibid., 12,

Miall, W. E., Ball, J., and Kellgren, J. H. (1958). Ibid. 17, 263.

Oshima, Y. (1961). "Atti del X Congress della Lega Internazionale contro il Reumatismo", vol. 욜, p. 1531. Ishizaki, T. Sasaki, S., and Kojima, J. (196 ब). Rheumatism, 2, 461.

Ravault, P. P., Vignon, G., and Robert, J. M. (1958्षे. Rev. Rhum., 25, 354.

Ropes, M. W., Bennett, G. A., Cobb, S., Jacox, R. Jessar, R. A. (1957). Ann. rheum. Dis., 16, $118 \overline{\text { a }}$ A

Social and Children's Bureaux, Welfare Ministry (1955).

"Survey on the Crippled and Disabled", issued $\overline{8 y}$

Welfare Ministry, Japan.

Statistical Section, Welfare Ministry (1959). "Nation 1 Survey on Health", Welfare Statistical Associttion, Japan.

Sze, T. S. (1963). In "The Epidemiology of Chronic Rheumatism", ed. J. H. Kellgren, M. R. Jeffre⿻ and J. Ball, p. 1. Blackwell Scientific Publications, Oxford.

Manifestations rhumatismales dans les populations urbaine et rurale d'Osaka

\section{RÉSUMÉ}

(1) On a procédé à une enquête sur la fréquence dẹs manifestations rhumatismales dans la population urbaine de Toyonaka et la population rurale de Topo, Tondabayashi, Osaka, comprenant un nombre total fe 5,019 personnes appartenant à 1,175 familles.

(2) $\mathrm{La}$ fréquence totale des manifestations rhumatismales était 7 pour cent, avec un pourcentage un peu plins grand dans la région rurale. Lorsqu'on tient compte des manifestations antécédentes, on trouve peu de différenęe entre les deux régions.

(3) On a trouvé l'arthrite rhumatismale en 0,3 pour cent de la population entière, avec peu de différence en Fुge les deux régions.

(4) L'arthrite rhumatismale inflammatoire a $\stackrel{?}{\text { ete }}$ trouvée en 0,9 pour cent à Toyonaka et en 0,5 pour centh à Tojo. Lorsqu'on y inclut les manifestations anfe- 
cédentes, le pourcentage urbain devient 1,4 pour cent et rural 0,8 pour cent

(5) Des maladies rhumatismales non-articulaires ont été trouvées en 3 pour cent ( 4 pour cent, si l'on tient compte du passé).

(6) On a observé des désordres des disques (lumbago et symptômes nerveux radiculaires) en 2,3 pour cent dans les deux régions étudiés et l'ostéo-arthrite en 1,6 pour cent, avec un excès dans la région rurale.

(7) On a comparé ces résultats avec ceux de Leigh en Angleterre. La fréquence des manifestations rhumatismales, particulièrement de l'arthrite rhumatismale et probablement de l'ostéo-arthrite était beaucoup plus basse au Japon.

\section{Manifestaciones reumáticas en las poblaciones urbana $\mathbf{y}$ rural de Osaka}

\section{SUMARIO}

(1) Se investigó la frecuencia de manifestaciones reumáticas en la población urbana de Toyonaka y en la población rural de Tojo, Tondabayashi, Osaka, con un nombre total de 5,019 personas, perteneciendo a 1,175 familias.
(2) La frecuencia total de manifestaciones reumaticas fué de un 7 por ciento, con un número algo mayor en la región rural. Cuando se tiene cuenta de las manifestaciones pasadas, se encuentra poca diferencia entre las dos poblaciones.

(3) La artritis reumatoide fué encontrada en un 0,3 por ciento de la población entera, con poca differencia entre las dos regiones.

(4) La artritis reumàtica inflamatoria fué encontrada en un 0,9 por ciento en Toyonaka y en un 0,5 por ciento en Tojo. Cuando se incluye las manifestaciones pasadas, las cifras urbanas llegan a un 1,4 por ciento $y$ las rurales a un 0,8 por ciento.

(5) Enfermedades reumàticas non-articulares encontráronse en un 3 por ciento ( 4 por ciento al considerar el pasado).

(6) Trastornos del disco (lumbago y síntomas radiculares de los nervios) se vieron en un 2,3 por ciento en ambas regiones investigadas y la osteo-artritis en un 1,6 por ciento, con un exceso en la región rural.

(7) Se compararon estos resultados con los de Leigh en Inglaterra. La frecuencia de las manifestaciones reumáticas, en particular de la artritis reumatoide $y$ probablemente de la osteo-artritis fué mucho menor en Japón. 